\title{
A review of new hormonal therapies for prostate cancer in black men: is there enough data?
}

\author{
Matthias E. Meunier ${ }^{1,2^{*}}$ (D) Pascal Blanchet ${ }^{3,4}$, Yann Neuzillet ${ }^{1,2}$, Thierry Lebret ${ }^{1,2}$ and Laurent Brureau ${ }^{3,4}$
}

\begin{abstract}
Background: Prostate cancer among black men is known to have specific molecular characteristics, especially the androgen receptor or enzymes related to the androgen metabolism. These targets are keys to the action of new hormonal therapies. Nevertheless, literature has a lack of data regarding black men. We aimed to gather the available literature data on new hormonal therapies among black populations.

Methods: We conducted a literature review from the PubMed / MEDLINE database until October 2020. All clinical studies of new hormonal therapies and black populations, regardless of methodology, were included.

Results: Four studies provided data on new hormonal therapies in black populations. Three studies reported a PSA decline in black patients treated with Abiraterone, higher in black men than in white men. Overall survival also appears to be higher in black patients treated with Abiraterone only or first.

Conclusion: Few articles have evaluated the effectiveness and safety of use of these treatments among black populations. The first results seem to show that Abiraterone can provide a benefit in overall survival in black populations. Prospective studies are needed to answer these questions in the future.
\end{abstract}

Keywords: Abiraterone, Apalutamide, Black men, Enzalutamide, Hormonotherapy, Prostate Cancer

\section{Background}

Prostate cancer $(\mathrm{PCa})$ is the second most common cancer and the fifth most deadly cancer in men worldwide [1]. The effect of castration on metastatic PCa by androgen injections has been known since the 1940s [2]. It has been since then the cornerstone of metastatic $\mathrm{PCa}$ care.

In the early 2000 s, the only treatment option for metastatic castration-resistant prostate cancer patients (mCRPC) was chemotherapy. Since then, new hormonal therapies (i.e Abiraterone, Enzalutamide and Apalutamide) have become the new standard of care for patients

\footnotetext{
* Correspondence: matthias.meunier@yahoo.fr

'Department of Urology, Foch Hospital, 40 rue Worth, 92150 Suresnes, France

${ }^{2}$ University of Versailles-Saint-Quentin-en-Yvelines, Versailles, France Full list of author information is available at the end of the article
}

with advanced or metastatic PCa. They have demonstrated their efficacy and safety, first in metastatic castration-resistant prostate cancer patients (mCRPC) $[3,4]$, then in patients with metastatic hormonesensitive prostate cancer (mHSPC) [5-7] and finally in non-metastatic patients castration-resistant patients (M0 CRPC) $[8,9]$. In addition to their simplicity of use related to their oral form and an acceptable tolerance profile, these treatments have shown a significant survival gain at advanced and metastatic stage.

Prostate cancer among black men is known to have specific molecular characteristics [10], especially the androgen receptor (AR) or enzymes related to the androgen metabolism (i.e CYP17). These targets are keys to the action of new hormonal therapies. Nevertheless, literature has a lack of data regarding black men. A recent

(c) The Author(s). 2021 Open Access This article is licensed under a Creative Commons Attribution 4.0 International License, which permits use, sharing, adaptation, distribution and reproduction in any medium or format, as long as you give appropriate credit to the original author(s) and the source, provide a link to the Creative Commons licence, and indicate if changes were made. The images or other third party material in this article are included in the article's Creative Commons licence, unless indicated otherwise in a credit line to the material. If material is not included in the article's Creative Commons licence and your intended use is not permitted by statutory regulation or exceeds the permitted use, you will need to obtain permission directly from the copyright holder. To view a copy of this licence, visit http://creativecommons.org/licenses/by/4.0/ The Creative Commons Public Domain Dedication waiver (http://creativecommons.org/publicdomain/zero/1.0/) applies to the data made available in this article, unless otherwise stated in a credit line to the data. 
analysis of 1,319,225 patients from the National Cancer Database (NCDB) demonstrates no racial survival disparities for African American and white men with bone, liver, lung, or brain metastasis [11]. Nevertheless, due to the lack of treatments related data, no conclusion could be drawn regarding the efficacy of new hormonal therapies in the black population.

We aimed to gather the available literature data on new hormonal therapies among black populations.

\section{Methods}

\section{Research strategy}

We conducted a literature review from the PubMed / MEDLINE database, with no date restrictions until october 2020, using the following keywords: "Abiraterone", "Apalutamide", "Darolutamide", "Enzalutamide" and "African men", "Black men". Due to the small number of studies published in English, all clinical studies of new hormonal therapies and black populations, regardless of methodology, were included. Abstract and reviews of literature have been excluded. The main outcomes were: the decline of prostate specific antigen (PSA), defined as efficacy or antitumor activity in the reported studies, survival results (overall survival and progression-free survival) and reported adverse events.

\section{Results}

Four studies were found, published between December 2016 and November 2019, evaluating the PSA decline, overall survival, progression-free survival and adverse events of new hormonal therapies. The characteristics of the patients included in these studies are summarized in Table 1 . In total, $n=1191$ patients were included in these studies, including 1116 patients for the retrospective cohort by Leuva et al. Three studies evaluated abiraterone only, and one abiraterone and/or enzalutamide with mostly abiraterone treated patients. Three of the four studies evaluated patients with $\mathrm{MCRPC}$, and one, patients with M0 CRPC. The median age of patients, when available was between 66 and 78 years. The grade groups, when available, where split in half between patients with low risk to intermediate risk (i.e. grade groups for Gleason score 1 to 3) and patients with high risk (i.e. grade groups for Gleason score 4 and 5). Most patients where asymptomatic and had a good performance status. One study was a large retrospective cohort, two were single-arm phase II studies with a prospective design, and one was a retrospective, comparative casecontrol study, with a level of evidence of respectively $2 b$, $2 c, 2 c$ and 4 , according to the levels of evidence for therapeutic studies from the centre for evidence-based medicine [16].

\section{PSA decline}

The only prospective single center study for patients with mCRPC demonstrated a 90\% antitumor activity (defined as a 30\% PSA level decline) of the Abiraterone among black men [12]. A retrospective comparative study showed a higher antitumor activity in black men with $\mathrm{MCRPC}$ than white men: statistically significant differences in favor of Black men were found in the proportion of patients achieving a 50\% PSA level decline (Black men 68.9\%, White men $48.9 \%, P=0.028$ ) and $30 \%$ PSA level decline (Black men $77.8 \%$, White men 54.4\%, $P=0.008)$. Rates of primary Abiraterone-refractory disease (PSA increase as best response) also trended to be higher in White men (31.1\%) than in Black men (15.6\%) patients $(P=0.052)[14]$.

Similarly, Leuva et al. found among a large sample of nearly 1000 black patients versus three thousand white patients that Abiraterone efficacy was 60\% higher in black men than in white men, using a novel approach

Table 1 Characteristics of selected trials

\begin{tabular}{|c|c|c|c|c|c|c|c|c|c|}
\hline Trial (NCT) & Study design & $\begin{array}{l}\text { Level of } \\
\text { evidence }\end{array}$ & Treatment & Population & $\begin{array}{l}\text { Number of } \\
\text { patients }(\mathrm{N})\end{array}$ & $\begin{array}{l}\text { Median } \\
\text { age }\end{array}$ & $\begin{array}{l}\text { Baseline } \\
\text { PSA }\end{array}$ & $\begin{array}{l}\text { Gleason } \\
\text { grade } \\
\text { groups }\end{array}$ & PS \\
\hline $\begin{array}{l}\text { Tsao et al. } 2016 \\
\text { NCT01735396 } \\
{[12]}\end{array}$ & Ph. II prospective study & $2 c$ & Abiraterone & $\begin{array}{l}\text { mCRPC } \\
\text { black men }\end{array}$ & 11 & 66 & NR & $N R$ & $\begin{array}{l}\text { OMS } \\
073 \% \\
\text { OMS } \\
127 \%\end{array}$ \\
\hline $\begin{array}{l}\text { Ryan et al. } \\
2018 \\
\text { NCT01314118 } \\
\text { [13] }\end{array}$ & Ph. II prospective study & $2 c$ & Abiraterone & MO CRPC & 19 & NR & NR & $N R$ & NR \\
\hline $\begin{array}{l}\text { Ramalingam } \\
\text { et al. } 2017 \text { [14] }\end{array}$ & $\begin{array}{l}\text { Retrospective } \\
\text { comparative case-control } \\
\text { study }\end{array}$ & 4 & Abiraterone & $\begin{array}{l}\text { mCRPC } \\
\text { black men }\end{array}$ & 45 & NR & NR & $\begin{array}{l}\text { Gr. 1-3 42\% } \\
\text { Gr. 4-5 58\% }\end{array}$ & $\begin{array}{l}\text { OMS } \\
092 \% \\
\text { OMS } \\
18 \%\end{array}$ \\
\hline $\begin{array}{l}\text { Leuva et al. } \\
2019 \text { [15] }\end{array}$ & $\begin{array}{l}\text { Retrospective cohort } \\
\text { study }\end{array}$ & $2 b$ & $\begin{array}{l}\text { Abiraterone and } \\
\text { Enzalutamide }\end{array}$ & $\begin{array}{l}\text { mCRPC } \\
\text { black men }\end{array}$ & 1116 & $73-78$ & $45.8-48.7$ & NR & NR \\
\hline
\end{tabular}


based on the growth and regression theory, using serial PSA values $(p=0.02)$. On the other hand, no difference between black and white patients treated with Enzalutamide was demonstrated [15].

\section{Survival outcomes}

Leuva et al. demonstrated that the overall survival of black patients was statistically significantly higher than that of white patients, with 3 months of survival benefit (25.4 months versus 22.4 months, $p=0.02$ ) in patients treated with Abiraterone only or with Abiraterone first (followed by Enzalutamide). These differences were unaffected by prior Taxane chemotherapy exposure. No difference of survival was reported between black and white patients treated with Enzalutamide [15].

A prospective comparative study between black and white men with M0 CRPC did not find any differences for PSA progression-free survival (median: 29.0 vs. 28.6 months, $p=0.57$ ) and radiological progression-free survival (median: 41.4 vs not reached, $p=0.82$ ) [13].

A retrospective comparative study also did not find any survival differences between black and white men with mCRPC: Median overall survival (Black men 27.3 months, White men 24.8 months, $P=0.669$ ) and median time to PSA progression (Black men 11.0 months, White men 9.4 months, $P=0.917$ ) [14].

\section{Adverse events}

Only one prospective study has fully reported adverse events. No patients discontinued treatment because of adverse events and treatment was well tolerated. Yet, Higher common events were reported than expected. For example, the authors report fatigue in $70 \%$ of patients, which is higher than the phase III studies carried out in a predominantly Caucasian population $[4,17]$. All these results are presented in Table 2.

\section{Discussion}

New hormonal therapies have been a revolution in the management of advanced and metastatic prostate cancer. Numerous large-scale prospective studies have shown both the efficacy and safety of these treatments. However, most of these multicentre studies have been conducted in North America, Europe or Asia, where populations contain only few black subjects [3-9]. In addition, ethnicity data of these patients is not specified. In practice, the new hormonal therapies are the reference treatment for prostate cancer, including for black populations, despite molecular specificities interfering with the mechanisms of action of the molecules used (i.e Abiraterone, Enzalutamide, Apatumide and Darolutamide).

Table 2 Outcomes of selected trials

\begin{tabular}{|c|c|c|c|c|c|c|}
\hline Trial (NCT) & Population & Comparison & $\begin{array}{l}\text { Primary } \\
\text { Outcomes }\end{array}$ & $\begin{array}{l}\text { Secondary } \\
\text { Outcomes }\end{array}$ & Results & $\begin{array}{l}\text { Adverse } \\
\text { Events }\end{array}$ \\
\hline $\begin{array}{l}\text { Tsao et al. } \\
2016 \\
\text { NCT017353 } \\
96[12]\end{array}$ & $\begin{array}{l}\text { mCRPC } \\
\text { black men }\end{array}$ & - & $\begin{array}{l}\text { Antitumor activity } \\
\text { (defined by a } 30 \% \\
\text { decline in PSA } \\
\text { level) }\end{array}$ & - & $90 \%$ antitumor activity & $\begin{array}{l}\text { No patients } \\
\text { discontinuing } \\
\text { treatment } \\
\text { because of AE } \\
\text { Higher } \\
\text { common AE }\end{array}$ \\
\hline $\begin{array}{l}\text { Ryan et al. } \\
2018 \\
\text { NCT0131411 } \\
8 \text { [13] }\end{array}$ & $\begin{array}{l}\text { MO CRPC } \\
\text { black men }\end{array}$ & $\begin{array}{l}\text { mCRPC } \\
\text { white men }\end{array}$ & $\begin{array}{l}\text { Rate of } 50 \% \text { PSA } \\
\text { decline }\end{array}$ & $\begin{array}{l}\text { Time to PSA and to } \mathrm{Rx} \\
\text { progression }\end{array}$ & $\begin{array}{l}\text { Primary: No data } \\
\text { Secondary: No difference }\end{array}$ & NR \\
\hline $\begin{array}{l}\text { Ramalingam } \\
\text { et al. } 2017 \\
{[14]}\end{array}$ & $\begin{array}{l}\text { mCRPC } \\
\text { black men }\end{array}$ & $\begin{array}{l}\text { mCRPC } \\
\text { white men } \\
(2 \mathrm{~W}: 1 \mathrm{~B})\end{array}$ & $\begin{array}{l}\text { Rate of } 90,50 \text { and } \\
30 \% \text { PSA decline }\end{array}$ & $\begin{array}{l}\text { Time on therapy, time to PSA } \\
\text { progression, OS }\end{array}$ & $\begin{array}{l}\text { Primary: } 90 \% \text { PSA did not differ } \\
\text { between B and W, but } 50 \text { and } \\
30 \% \text { decline were significantly } \\
\text { higher among B } \\
\text { Secondary: time on therapy, time } \\
\text { to PSA progression and OS did } \\
\text { not differ between B and W }\end{array}$ & NR \\
\hline $\begin{array}{l}\text { Leuva et al. } \\
2019 \text { [15] }\end{array}$ & $\begin{array}{l}\text { mCRPC } \\
\text { black men }\end{array}$ & $\begin{array}{l}\text { mCRPC } \\
\text { white men }\end{array}$ & Overall survival & $\begin{array}{l}\text { Efficacy of treatment using } \\
\text { tumor growth and regression, } \\
\text { were calculated using serial } \\
\text { PSA values }\end{array}$ & $\begin{array}{l}\text { B Patients treated with Abi only or } \\
\text { with Abi first showed superior } \\
\text { survival than W patients: } \\
25.4 \text { months vs. } 22.4 \text { months } \\
\text { ( } p=0.02 \text { ) } \\
\text { Abi efficacy was } 60 \% \text { higher in B } \\
\text { than in W patients } \\
\text { ( } p=0.02 \text { ) } \\
\text { No difference between B and W } \\
\text { patients treated with Enza }\end{array}$ & NR \\
\hline
\end{tabular}


Table 3 Ongoing prospective studies, evaluating new hormonal therapies in black populations

\begin{tabular}{lllll}
\hline Trial (NCT) & Study design & Treatment & Population & Number of patients (N) \\
\hline NCT02415621 & Phase I & Abiraterone & mCRPC & 10 \\
NCT03770455 & Phase II & Abiraterone or Enzalutamide + Avelumab & mCRPC & 27 \\
NCT01940276 & Phase II & Abiraterone & mCRPC & 50 \\
NCT03098836 & Phase II & Abiraterone + Apalutamide & mCRPC & 50 \\
\hline
\end{tabular}

Abiraterone is an androgen biosynthesis inhibitor, that inhibits 17 a-hydroxylase/C17,20-lyase (CYP17). The results of meta-analysis suggest that CYP17 polymorphisms may have a role in PCa susceptibility in African Americans [18, 19]. Notably, rs743572 polymorphism seems to be associated with a higher PCa risk in the black population, but not in Caucasian or Asian population [20]. Mutations in genes encoding the target might lead to a different efficiency of the molecule in the black population.

Enzalutamide as well as Apalutamide and Darolutamide are AR inhibitors that inhibit multiple steps in the AR signaling pathway. Comparing mutations of 200 black men versus 100 white men, Koochekpour et al. found that somatic missense AR mutations were detected at a higher rate in black men (17 out of 200 cases) than in white men (2 out of 100 cases). Analysis of genomic DNAs extracted from white blood cells of patients with sporadic PCa revealed that the rate of germline AR mutations were also 4 times higher in black men than in white men [21]. Gaston et al. found that AR protein expression was $81 \%$ higher in localized PCa of black men compared to white men [22]. Even though, due to a lack of data, no difference was found in our review for these new AR inhibitors, AR mutations and expression could result in a differentiated effect of these treatments depending on race.

Only four studies were found to provide data on new hormonal therapies in black populations, including three study for Abiraterone only, and one large scale study with 90\% treated with Abiraterone only or Abiraterone first. These studies have showed a real PSA decline with Abiraterone, which seems to be higher in black population than in white population. Concordantly, Leuva et al. found that Black men treated with Abiraterone only or first, presented a higher overall survival. Molecular specificities of prostate cancer among black men might allow a better efficacy of Abiraterone in this population.

NCT01940276 is a prospective multicenter trial currently underway, comparing black and white men with mCRPC receiving Abiraterone. The first results are similar to previous findings, showing that PSA progressionfree survival was higher among black men than white men [23]. McNamara et al. also recently reported retrospective data comparing mCRPC chemotherapy-naïve black $(n=787)$ and white patients $(n=2123)$. Black men had better overall survival than white men with 918 days and 781 days respectively (HR $=0.826$; 95\%CI $[0.732$ 0.933]) [24]. These preliminary data seem to confirm the survival benefit for black patients with $\mathrm{mCRPC}$ treated with Abiraterone.

Several prospective studies are currently evaluating Abiraterone, Enzalutamide or Apalutamide as well as combinations, focusing on black populations. None were found in this population on Darolutamide. We present a summary of ongoing prospective studies in Table 3.

Regarding adverse events, few data are available. Even though in the Tsao et al. study incidence of some common adverse effects may have been higher than expected due to small sample size, adverse events seemed to be similar by frequency and severity by race in the first results of the prospective trial NCT01940276 conducted among black and white subjects [23].

However, these studies are insufficient and large multicenter prospective studies among black populations, with Caucasian control group, would be needed to specifically address the questions of efficacy, survival benefit and security of treatment with new hormonal therapies in black men, especially regarding Abiraterone.

\section{Conclusion}

After an inventory of the literature, few articles have evaluated the effectiveness and safety of use of these treatments among black populations. The first results seem to show that Abiraterone can provide a benefit in overall survival in black populations. New large prospective studies are needed to answer these questions in the future.

\section{Abbreviations \\ AR: Androgen receptor; MO CRPC: Non-metastatic patients castration- resistant patients; mCRPC: Metastatic castration-resistant prostate cancer pa- tients; mHSPC: Metastatic hormone-sensitive prostate cancer; PCa: Prostate cancer; PSA: Prostate-Specific Antigen}

\section{Acknowledgements}

Foch Hospital and University Hospital of Guadeloupe.

\section{Authors' contributions}

MM analyzed and interpreted the patient data, and was a major contributor in writing the manuscript. PB, YN and TL have made substantial

contributions to the revision of the manuscript. LB has made substantial contributions to the conception and the revision of the manuscript. All authors read and approved the final manuscript. 
Funding

None.

Availability of data and materials

Not applicable.

Ethics approval and consent to participate

Not applicable.

\section{Consent for publication}

Not applicable.

\section{Competing interests}

The authors declare that they have no competing interests.

\section{Author details}

'Department of Urology, Foch Hospital, 40 rue Worth, 92150 Suresnes, France. ${ }^{2}$ University of Versailles-Saint-Quentin-en-Yvelines, Versailles, France. ${ }^{3}$ Department of Urology, Pointe-à-Pitre University Hospital, Pointe-à-Pitre, Guadeloupe, France. ${ }^{4}$ Inserm, UMR_S 1085 - IRSET, Pointe-à-Pitre,

Guadeloupe, France.

Received: 23 March 2020 Accepted: 30 December 2020

Published online: 14 January 2021

\section{References}

1. Ferlay J, Soerjomataram I, Dikshit R, et al. Cancer incidence and mortality worldwide: sources, methods and major patterns in GLOBOCAN 2012. Int Cancer. 2015;136(5):E359-86. https://doi.org/10.1002/ijc.29210.

2. Huggins C, Hodges CV. Studies on prostatic Cancer. I. the effect of castration, of estrogen and of androgen injection on serum phosphatases in metastatic carcinoma of the prostate. Cancer Res. 1941;1(4):293-7.

3. Beer TM, Armstrong AJ, Rathkopf DE, et al. Enzalutamide in metastatic prostate cancer before chemotherapy. N Engl J Med. 2014;371(5):424-33. https://doi.org/10.1056/NEJMoa1405095.

4. Ryan CJ, Smith MR, Fizazi K, et al. Abiraterone acetate plus prednisone versus placebo plus prednisone in chemotherapy-naive men with metastatic castration-resistant prostate cancer (COU-AA-302): final overall survival analysis of a randomised, double-blind, placebo-controlled phase 3 study. Lancet Oncol. 2015;16(2):152-60. https://doi.org/10.1016/S14702045(14)71205-7.

5. Fizazi K, Tran N, Fein L, et al. Abiraterone plus prednisone in metastatic, castration-sensitive prostate Cancer. N Engl J Med. 2017:377(4):352-60. https://doi.org/10.1056/NEJMoa1704174.

6. James ND, de Bono JS, Spears MR, et al. Abiraterone for prostate Cancer not previously treated with hormone therapy. N Engl J Med. 2017;377(4):338-51. https://doi.org/10.1056/NEJMoa1702900

7. Davis ID, Martin AJ, Stockler MR, et al. Enzalutamide with standard first-line therapy in metastatic prostate Cancer. N Engl J Med. 2019;381(2):121-31. https://doi.org/10.1056/NEJMoa1903835.

8. Hussain M, Fizazi K, Saad F, et al. Enzalutamide in men with nonmetastatic castration-resistant prostate Cancer. N Engl J Med. 2018;378(26):2465-74 https://doi.org/10.1056/NEJMoa1800536.

9. Smith MR, Saad F, Chowdhury S, et al. Apalutamide treatment and metastasis-free survival in prostate Cancer. N Engl J Med. 2018;378(15):140818. https://doi.org/10.1056/NEJMoa1715546.

10. Singh SK, Lillard JW, Singh R. Molecular basis for prostate cancer racial disparities. Front Biosci Landmark Ed. 2017;22:428-50.

11. Vengaloor Thomas T, Gordy XZ, Lirette ST, et al. Lack of racial survival differences in metastatic prostate Cancer in National Cancer Data Base (NCDB): a different finding compared to non-metastatic disease. Front Oncol. 2020;10. https://doi.org/10.3389/fonc.2020.533070.

12. Tsao C-K, Sfakianos J, Liaw B, et al. Phase II trial of Abiraterone acetate plus prednisone in black men with metastatic prostate Cancer. Oncologist. 2016; 21(12):1414-e9. https://doi.org/10.1634/theoncologist.2016-0026.

13. Ryan CJ, Crawford ED, Shore ND, et al. The IMAAGEN study: effect of Abiraterone acetate and prednisone on prostate specific antigen and radiographic disease progression in patients with nonmetastatic castration resistant prostate Cancer. J Urol. 2018;200(2):344-52. https://doi.org/10.1016/ j.juro.2018.03.125.
14. Ramalingam S, Humeniuk MS, Hu R, et al. Prostate-specific antigen response in black and white patients treated with abiraterone acetate for metastatic castrate-resistant prostate cancer. Urol Oncol. 2017;35(6):418-24. https://doi. org/10.1016/j.urolonc.2016.12.016

15. Leuva H, Sigel K, Zhou M, et al. A novel approach to assess real-world efficacy of cancer therapy in metastatic prostate cancer. Analysis of national data on veterans treated with abiraterone and enzalutamide. Semin Oncol. 2019;46(4-5):351-61. https://doi.org/10.1053/j.seminoncol.2019.11.004.

16. Oxford Centre for Evidence-based Medicine - Levels of Evidence (March 2009). CEBM Published June 11, 2009. Accessed August 1, 2020. https:// www.cebm.net/2009/06/oxford-centre-evidence-based-medicine-levelsevidence-march-2009/

17. Ryan CJ, Smith MR, de Bono JS, et al. Abiraterone in metastatic prostate cancer without previous chemotherapy. N Engl J Med. 2013;368(2):138-48. https://doi.org/10.1056/NEJMoa1209096.

18. Ntais C, Polycarpou A, loannidis JPA. Association of the CYP17 gene polymorphism with the risk of prostate cancer: a meta-analysis. Cancer Epidemiol Biomark Prev Publ Am Assoc Cancer Res Cosponsored Am Soc Prev Oncol. 2003;12(2):120-6.

19. Ragin CC, Langevin S, Rubin S, Taioli E. Review of studies on metabolic genes and cancer in populations of African descent. Genet Med. 2010;12(1): 12-8. https://doi.org/10.1097/GIM.0b013e3181c8e160.

20. Wang F, Zou Y-F, Feng X-L, Su H, Huang F. CYP17 gene polymorphisms and prostate cancer risk: a meta-analysis based on 38 independent studies. Prostate. 2011;71(11):1167-77. https://doi.org/10.1002/pros.21332.

21. Koochekpour S, Buckles E, Shourideh M, et al. Androgen receptor mutations and polymorphisms in African American prostate cancer. Int J Biol Sci. 2014; 10(6):643-51. https://doi.org/10.7150/ijbs.8974.

22. Gaston KE, Kim D, Singh S, Ford OH, Mohler JL. Racial differences in androgen receptor protein expression in men with clinically localized prostate cancer. J Urol. 2003;170(3):990-3. https://doi.org/10.1097/01.ju. 0000079761.56154.e5.

23. George DJ, Heath El, Sartor AO, et al. Abi Race: A prospective, multicenter study of black (B) and white (W) patients (pts) with metastatic castrate resistant prostate cancer $(\mathrm{MCRPC})$ treated with abiraterone acetate and prednisone (AAP). J Clin Oncol. 2018;36(18_suppl):LBA5009. https://doi.org/ 10.1200/JCO.2018.36.18_suppl.LBA5009.

24. McNamara MA, George DJ, Ramaswamy K, et al. Overall survival by race in chemotherapy-naïve metastatic castration-resistant prostate cancer (mCRPC) patients treated with abiraterone acetate or enzalutamide. J Clin Oncol. 2019;37(7_suppl):212. https://doi.org/10.1200/JCO.2019.37.7_suppl.212.

\section{Publisher's Note}

Springer Nature remains neutral with regard to jurisdictional claims in published maps and institutional affiliations.

Ready to submit your research? Choose BMC and benefit from:

- fast, convenient online submission

- thorough peer review by experienced researchers in your field

- rapid publication on acceptance

- support for research data, including large and complex data types

- gold Open Access which fosters wider collaboration and increased citations

- maximum visibility for your research: over $100 \mathrm{M}$ website views per year

At $\mathrm{BMC}$, research is always in progress.

Learn more biomedcentral.com/submissions 